Pak. j. sci. ind. res. Ser. A: phys. sci. 201255 (1) 43-48

\title{
Optimization of Coagulation Process for the Treatment of the Characterized Slaughterhouse Wastewater
}

\author{
Muhammad Tariq ${ }^{\mathrm{a}}$, Mahtab Ahmad ${ }^{\mathrm{a}}$, Shumaila Siddique ${ }^{\mathrm{b}}$, Abdul Waheed ${ }^{\mathrm{b}}$, \\ Tahira Shafiq ${ }^{a}$ and Muhammad Hammad Khan ${ }^{\text {a* }}$ \\ ${ }^{a}$ Centre for Environmental Protection Studies, PCSIR Laboratories Complex, Lahore-54600, Pakistan \\ ${ }^{b}$ Department of Chemistry, Forman Christian College and Charted University, Lahore, Pakistan
}

(received October 10, 2010; revised March 5, 2011; accepted April 30, 2011)

\begin{abstract}
The wastewater of a slaughterhouse was characterized for parameters like $\mathrm{pH}, \mathrm{COD}, \mathrm{BOD}$, TDS and TSS. All parameters were above the permissible limits of National Environmental Quality Standards of Pakistan. The slaughterhouse wastewater is rich in organic matter with BOD and COD being $5820 \mathrm{mg} / \mathrm{L}$ and $6970 \mathrm{mg} / \mathrm{L}$, respectively. In this study, wastewater was treated by coagulation process using lime and alum (both individually and in combination) as coagulants. COD removal increased with increase in alum dose to a maximum of $92 \%$. The high sludge volume made the process infeasible. Increase in lime dose increased the COD reduction to a maximum of $74 \%$. The sludge settling speed was very high and sludge volume was low as compared with alum. The combined doses of lime and alum gave removal of COD to a maximum of $85 \%$ with sludge volume comparable to lime. The optimum dose of lime and alum reduced BOD, TSS, and TDS to a maximum of $85 \%, 98 \%$ and $77 \%$, respectively. The combination of coagulation/precipitation gave enhanced COD removal with minimal sludge produced.
\end{abstract}

Keywords: slaughterhouse, wastewater, coagulation, alum, lime, sludge volume

\section{Introduction}

Slaughterhouse wastewater (SHW) causes harmful impact on the environment of receiving water body. They are high in organic content. Effluents discharged from slaughterhouses cause the deoxygenation of rivers (Quinn and McFarlane, 1989) and the contamination of groundwater (Sangodoyin and Agbawhe, 1992). The pollution potential of meat-processing and slaughterhouse plants has been estimated to be over 1 million population equivalent in the Netherlands' and 3 million in France (Sayed, 1987). Blood has chemical oxygen demand (COD) of $375,000 \mathrm{mg} / \mathrm{L}$ which is one of the major dissolved pollutants in slaughterhouse wastewater (Tritt and Schuchardt, 1992). In addition, slaughterhouse wastewater contains high concentrations of suspended solids (SS), including pieces of fat, grease, hair, feathers, flesh, manure, grit, and undigested feed (Tritt and Schuchardt, 1992).

Slaughterhouse wastewater quality depends on blood retention during animal bleeding. This is considered to be an important measure for reducing biological oxygen demand (BOD) (Sayed et al., 1988). Water economy usually translates into increased pollutant concentration, although total BOD mass will remain constant. BOD

*Author for correspondence; E-mail: jawad_fre@hotmail.com is higher in wastewater from beef slaughterhouse than hog slaughterhouse (Tritt and Schuchardt, 1992).

Most of the slaughterhouse wastewater quality data comes from Europe (Sayed, 1987; Bull et al., 1982), Australia (Quinn and McFarlane, 1989) and the USA (Johns, 1995). The wastes produced by animal slaughtering are biodegradable and if properly managed it provides nutrients to plants. But it becomes highly polluting when put to drain without proper treatment causing deoxygenation of receiving water body posing life threat to aquatic life and ultimately cause red-tide and eutrophication. Moreover, the effluent is a source of dangerous microbes and drug-resistant bacteria into water supplies causing various water borne diseases like cholera and diarrhoea. Slaughterhouse effluent also produces toxic gases such as ammonia, hydrogen sulfide and methane.

The processes like coagulation, ozonation and biological process are being used for wastewater treatment depending upon the nature of wastewater (Khan et al., 2010; Khan and Jung, 2008; Tchobanoglous et al., 2003; Johns, 1995; Sayed et al., 1988). The process of coagulation/flocculation is under extensive study for improvement of slaughterhouse waste treatment (Amuda and Alade, 2006; Aguilar et al., 2005). These insoluble and slowly biodegradable suspended solid (SS) 
represents $50 \%$ of the pollution charge in screened $(1 \mathrm{~mm})$ slaughterhouse wastewater, while another $25 \%$ originated from colloidal solids (Bull et al., 1982). Under the stable conditions, the attractive forces between particles are considerably less than the repelling forces due to the net negative surface charge on colloidal particles (Tchobanoglous et al., 2003). Brownian motion keeps the particles in suspended state. In the process of coagulation the colloidal particles are destabilized resulting in particle growth to a flock as a result of particle collision. Gravity separation (sedimentation or flotation) removes the coagulant flocks from water. Coagulation process depends upon the (1) particle size and number, (2) particle shape and flexibility, (3) surface properties including electrical characteristics, (4) particleparticle interaction and (5) particle-solvent interactions (Shaw, 1966). Coagulation/flocculation processes are commonly used to remove suspended matter or colour.

Alum treatment is a coagulation/flocculation process in which the hydrolysis products of alum causes coagulation and destabilize the colloidal state of the particles in wastewater. The gelatinous precipitates of the hydrolysis products of aluminum attach themselves with the colloidal particles and the flocks formed settle under gravity depending upon the density of particle and liquid. The lime treatment is a chemical precipitation process. In this process calcium carbonate formed is slightly soluble in water and excessive quantity precipitates and the particles in the wastewater settle by attachment with these precipitates.

The most commonly used coagulants are polyelectrolytes or multivalent cations like aluminum, iron, calcium or magnesium. These chemicals, under appropriate $\mathrm{pH}$, react with water to form insoluble hydroxides which link together to form long chains or meshes, physically trapping small particles into the larger flock (Tchobanoglous et al., 2003).

$$
\begin{aligned}
& {\left[\mathrm{Al}\left(\mathrm{H}_{2} \mathrm{O}\right)_{6}\right]^{3+} \stackrel{\mathrm{OH}^{-}}{\longrightarrow}\left[\mathrm{Al}(\mathrm{OH})\left(\mathrm{H}_{2} \mathrm{O}\right)_{5}\right] \stackrel{\mathrm{OH}^{-}}{\longrightarrow}} \\
& {\left[\mathrm{Al}(\mathrm{OH})_{2}\left(\mathrm{H}_{2} \mathrm{O}\right)_{4}\right] \stackrel{\mathrm{OH}^{-}}{\longrightarrow}} \\
& {\left[\mathrm{Al}(\mathrm{OH})_{3}\left(\mathrm{H}_{2} \mathrm{O}\right)_{3}\right](\mathrm{s}) \stackrel{\mathrm{OH}^{-}}{\longrightarrow}\left[\mathrm{Al}(\mathrm{OH})_{4}\left(\mathrm{H}_{2} \mathrm{O}\right)_{2}\right]}
\end{aligned}
$$

Prior to the production of aluminate ion polymerization takes place as follows (Shaw, 1966):

$$
\left[\mathrm{Me}(\mathrm{OH})\left(\mathrm{H}_{2} \mathrm{O}\right)_{5}\right]^{2+} \leftrightarrow\left[\left(\mathrm{H}_{2} \mathrm{O}\right)_{4} \mathrm{Me}_{\mathrm{OH}}^{\mathrm{OH}} \mathrm{Me}\left(\mathrm{H}_{2} \mathrm{O}\right)_{4}\right]+2 \mathrm{H}_{2} \mathrm{O}
$$

These hydrolysis products can cause coagulation by (1) adsorption and charge neutralization, (2) Adsorption and inter-particle bridging and (3) enmeshment in sweep flock (Thomas, 1934). When alum is added to wastewater, it forms the precipitate of $\mathrm{Al}(\mathrm{OH})_{3}$ on reaction with calcium bicarbonate alkalinity, as follows (Tchobanoglous et al., 2003):

$3 \mathrm{Ca}\left(\mathrm{HCO}_{3}\right)_{2}+\mathrm{Al}_{2}\left(\mathrm{SO}_{4}\right)_{3} .18\left(\mathrm{H}_{2} \mathrm{O}\right) \leftrightarrow 2 \mathrm{Al}(\mathrm{OH})_{3}+$ $3 \mathrm{CaSO}_{4}+6 \mathrm{CO}_{2}+18 \mathrm{H}_{2} \mathrm{O}$

Lime reacts with calcium bicarbonate alkalinity and gives precipitates as follows (Tchobanoglous et al., 2003):

$\mathrm{Ca}\left(\mathrm{HCO}_{3}\right)_{2}+\mathrm{Ca}(\mathrm{OH})_{2} \leftrightarrow 2 \mathrm{CaCO}_{3}+2 \mathrm{H}_{2} \mathrm{O}$

This study was divided in two stages. In first stage, assessment of slaughterhouse wastewater quality compared with the National Environmental Quality Standards (NEQS, 1993) to determine the pollution load. In second stage, the wastewater was treated with different coagulants, to reduce the pollution load. Parameters were optimized to increase removal of various pollutants in the slaughterhouse effluent and to keep the sludge settling time and sludge volume at a minimum.

\section{Materials and Methods}

Materials. Chemicals and reagents used during analysis and treatment were of analytical grade obtained from E- Merck Germany and used without further purification. Various reagents used for this work were prepared in accordance with standard methods.

Survey and characterization of slaughterhouse effluent. Slaughterhouse located at Bakar Mandi, Band Road, Lahore, Pakistan (BML) was visited and found that it has two major portions; beef section for cow, buffalo and camels slaughtering and meat section for sheep and goat slaughtering. All the drains from each section fall in the main drain of slaughterhouse which is $200 \mathrm{~m}$ long and ultimately falls in the municipal drain. Slaughtering is performed five days a week in two shifts of three hours each day. Grab samples were collected from the main drain of slaughterhouse every 30 min and collected to get a composite sample for six working hours. About 30 liters of composite sample was taken to laboratory where it was mixed and homogenized.

Physical appearance of slaughterhouse effluent indicated reddish brown liquid with malodorous odour. Also the 
effluent contained blood clots, hairs and stomach waste particles. The slaughterhouse effluent samples were analyzed for the following parameters by the methods reported in the Standard Methods for the Examination of Water and Wastewater (APHA, 1998) mentioned by method numbers in parenthesis:

- $\mathrm{pH}\left(4500 \mathrm{H}^{+} \mathrm{B}\right)$,

- $\mathrm{TDS}=$ total dissolved solids $(2540 \mathrm{C})$,

- $\mathrm{TSS}=$ total suspended solids (2540 D),

- $\mathrm{COD}=$ chemical oxygen demand (5220 B)

- $\mathrm{BOD}=$ biochemical oxygen demand (5210 B)

Effluent treatment. Characterization of slaughterhouse effluent for the selected parameter indicated a heavy pollution load in the effluent. Different biological and chemical methods are being used for the treatment of wastewater. In the present work, chemical treatment of wastewater by coagulation was applied to treat the slaughterhouse effluent. The coagulants such as alum, lime and combination of both were used for treatment of wastewater.

Lime and alum were used separately as coagulant to treat the slaughterhouse effluent. Lime and alum solution of $10 \%$ strength were prepared and different volumes of these solutions were added to wastewater to make the predefined concentrations of these chemicals. The slaughterhouse effluent $(500 \mathrm{~mL})$ was taken in a series of 1-liter cylinders. Different incremental doses of the lime solution were added in each cylinder to get the lime dose of 1.0, 1.5, 2.0, 2.5 and $3.0 \mathrm{~g}$. The samples were mixed thoroughly for about 30 seconds at a speed of $100 \mathrm{rpm}$ and allowed the sludge formed to settle down. The same above procedure was employed for treatment of slaughterhouse wastewater with the alum dose of $1.0,1.5,2.0,2.5$ and $3.0 \mathrm{~g}$ for $500 \mathrm{~mL}$ of wastewater.

In the second stage of this experiment combinations of lime and alum were applied for the slaughterhouse effluent treatment. The slaughterhouse effluent $(500 \mathrm{~mL})$, taken in a series of $1 \mathrm{~L}$ cylinders, was dosed simultaneously with a fixed amount of lime $(2.5 \mathrm{~g})$ and an incremental amount of alum $(0.5,0.7$ and $0.9 \mathrm{~g})$. The mixtures were stirred thoroughly for 30 seconds at a speed of $100 \mathrm{rpm}$ and allowed to settle. The physical observations made after 30,60 and $120 \mathrm{~min}$ and samples taken at 120 min were analyzed for chemical parameters. Based on above reaction coagulant dose was optimized and one reaction was performed at the optimal conditions to get the maximum wastewater treatment.

\section{Results and Discussion}

Characterization of slaughterhouse effluent. Table 1 presents the analysis results of slaughterhouse effluent. The effluent was neutral in $\mathrm{pH}$ and reddish brown in colour. These values of other parameters were compared with National Environmental Quality Standards (NEQS, 1993) set by Environmental Protection Agency (EPA), Pakistan. It was found that all values except $\mathrm{pH}$ were tremendously higher than NEQS. COD and BOD were about 46.5 times and 72.7 times higher than NEQS (1993), respectively. While 11.2 and 3.2 times higher values than NEQS (1993) for TSS and TDS, respectively were observed. These values for various parameters indicated a high pollution load in the slaughterhouse effluent and point out a dire need for treatment before release into municipal drain.

Table 1. Characterization of slaughterhouse effluent

\begin{tabular}{lll}
\hline \hline Parameters & Value & NEQS \\
\hline $\mathrm{pH}$ & 6.70 & $6-10$ \\
$\mathrm{COD}$ & $6970 \mathrm{mg} / \mathrm{L}$ & $150 \mathrm{mg} / \mathrm{L}$ \\
$\mathrm{BOD}$ & $5820 \mathrm{mg} / \mathrm{L}$ & $80 \mathrm{mg} / \mathrm{L}$ \\
$\mathrm{TSS}$ & $2250 \mathrm{mg} / \mathrm{L}$ & $200 \mathrm{mg} / \mathrm{L}$ \\
TDS & $11250 \mathrm{mg} / \mathrm{L}$ & $3500 \mathrm{mg} / \mathrm{L}$ \\
\hline \hline
\end{tabular}

Treatment by coagulation. Treatment of slaughterhouse wastewater with alum gave very encouraging results regarding the removal of COD (Fig. 1A). The COD removal increased from 68 to $92 \%$ with increase in alum dose from 1.0 to $2.5 \mathrm{~g}$. Further increase in alum dose gave no improvement in results. Regarding the cost efficiency of the treatment, increase in alum dose decreased the COD removal per gram of coagulant very sharply from $2.4 \mathrm{~g} \mathrm{COD} / \mathrm{g}$ alum to about $1.1 \mathrm{~g} \mathrm{COD} / \mathrm{g}$ alum. The volume of sludge produced increased from about $120 \mathrm{~mL}$ to $400 \mathrm{~mL}$ when alum was increased from 1.0 to $3.0 \mathrm{~g}$. The speed of sludge settling also decreased drastically with increasing the alum dose and even after $2 \mathrm{~h}$ of settling, sludge could decrease to about $400 \mathrm{~mL}$ and further settling was almost negligible (Fig. 2A). The colour of treated wastewater was light reddish brown, light brown, yellowish brown and pale brown with alum dose of 1.0, 1.5, 2.0, 2.5 and $3.0 \mathrm{~g}$, respectively. The optimum alum dose, with reference to removal and cost efficiency was $2.5 \mathrm{~g}$ for $500 \mathrm{~mL}$ of 


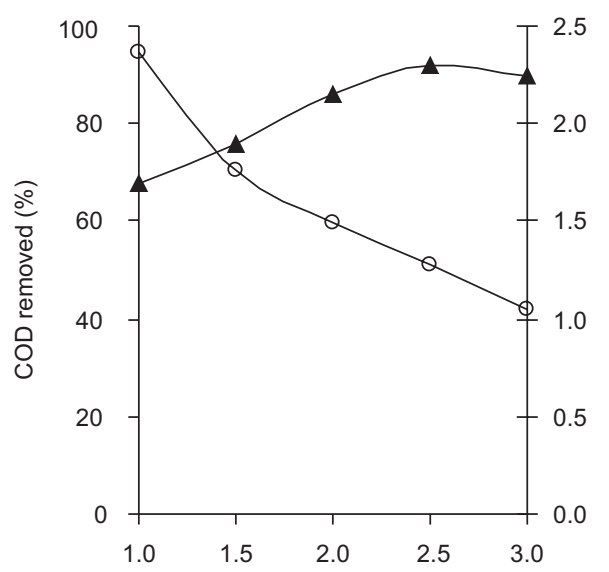

A

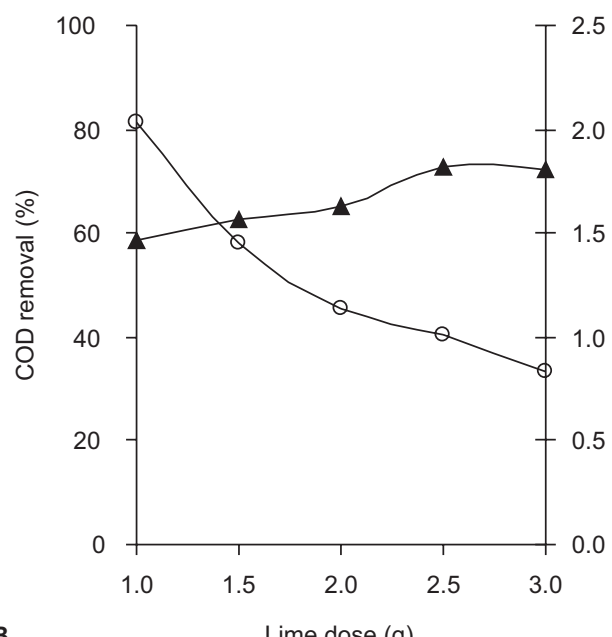

B

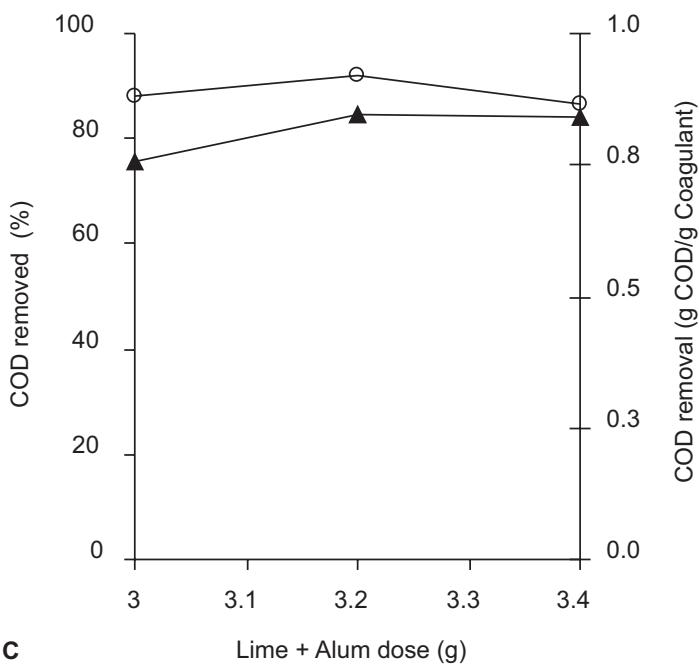

Fig. 1(A-C). 1: COD removal $(\boldsymbol{\Delta})$ and removal efficiency (o), with increasing dose of coagulants (A) Alum (B) Lime and (C) Lime + alum. slaughterhouse wastewater. These results showed that alum is a very efficient coagulant giving very high COD removal and it could destabilize the colloids formed in the wastewater. But due to small particles and high organic contents of wastewater the flocculation process of sludge settling was very slow which decreased the cost efficiency of this process.

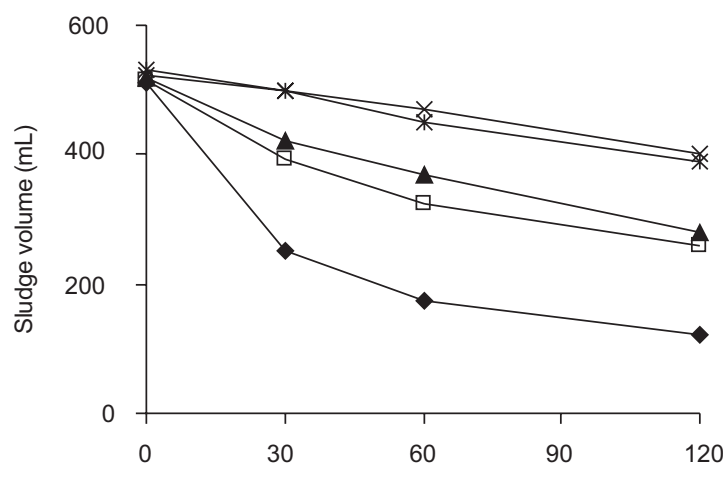

A

Settling time (min with Alum)

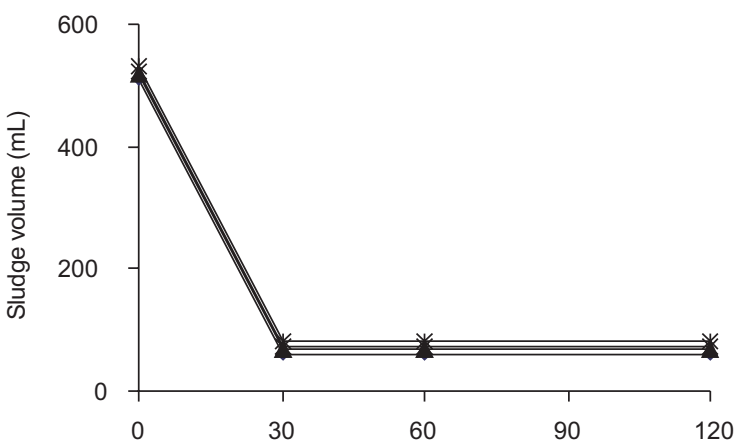

B

Settling time (min with Lime)

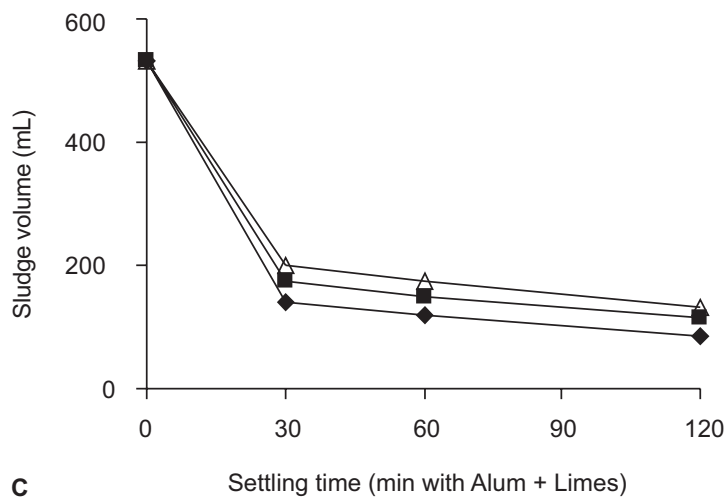

Fig. 2(A-C). Settling of sludge with the passage of time with coagulants (A) Alum, (B) Lime, (C) Lime + Alum. $\diamond=1.0 \mathrm{~g}, \square=1.5 \mathrm{~g}$, $\Delta=2.0 \mathrm{~g}, \times=2.5 \mathrm{~g}, *=3.0 \mathrm{~g}$, coagulant doses. 
Lime treatment of slaughterhouse wastewater also increased the COD removal with increasing the lime dose from $48 \%$ to $65 \%$ with increasing the dose from 1.0 to $2.5 \mathrm{~g}$ (Fig. 1B). Further, addition of lime gave no improved results. Cost efficiency of lime treatment decreased from 2.2 to $0.7 \mathrm{~g} \mathrm{COD} / \mathrm{g}$ lime with increase in lime dose from 1.0 to $3.0 \mathrm{~g}$. Lime treatment was not found to be very efficient for COD removal. The sludge formed in the lime treatment settled very fast in all the cases and after $30 \mathrm{~min}$ of settling no further settling was observed (Fig. 2B). The quantity of sludge increased from 60 to $80 \mathrm{~mL}$ with increasing the lime dose from 1.0 to $3.0 \mathrm{~g}$. The colour of treated wastewater was reddish brown, light brown, yellowing brown and yellowish brown with lime dose of 1.0, 1.5, 2.0, 2.5 and $3.0 \mathrm{~g}$, respectively. Lime was found to be very efficient regarding the settling time and quantity of sludge formed.

In this study, the colloidal particles were destabilized effectively as shown by the high COD removal. The flocculation process could not settle the sludge effectively as was seen in the high sludge volume and low settling speed. COD removal by lime was not very efficient as compared to alum. The precipitates formed in this study were heavier than alum and settled very fast and efficiently. Therefore, a combination of alum and lime was used in the next step of wastewater treatment to combine the coagulation efficiency of alum and the sludge settling efficiency of lime.

During the treatment with lime, optimum COD was removed with $2.5 \mathrm{~g}$ lime. For the combined treatment $2.5 \mathrm{~g}$ lime and varying doses of alum were added to wastewater. Alum was a good coagulant as it removed above $60 \%$ of COD with $10 \mathrm{~mL}$ alum solution. Therefore, $0.5,0.7$ and $0.9 \mathrm{~g}$ alum was added to each cylinder during combined coagulation test in addition to lime $(2.5 \mathrm{~g})$. In this test COD removal increased from $75 \%$ to $86 \%$ with alum dose increasing from 0.5 to $0.7 \mathrm{~g}$ (Fig. 1C). The results with $0.9 \mathrm{~g}$ alum dose were similar to $0.7 \mathrm{~g}$ alum. In the combined lime and alum coagulation process sludge settled faster than alum alone but slower than lime alone (Fig. 2C). The colour of treated wastewater was pale brown, light yellowish brown and pale yellowish brown for alum dose of 0.5, 0.7 and $0.9 \mathrm{~g}$ in addition to $2.5 \mathrm{~g}$ lime, respectively. The optimized dose of both coagulants i.e. $2.5 \mathrm{~g}$ lime and $0.7 \mathrm{~g}$ alum was applied to $500 \mathrm{~mL}$ slaughterhouse effluent and the supernatant was analyzed for various parameters in addition to COD i.e. $\mathrm{pH}, \mathrm{BOD}$, TSS and TDS. The

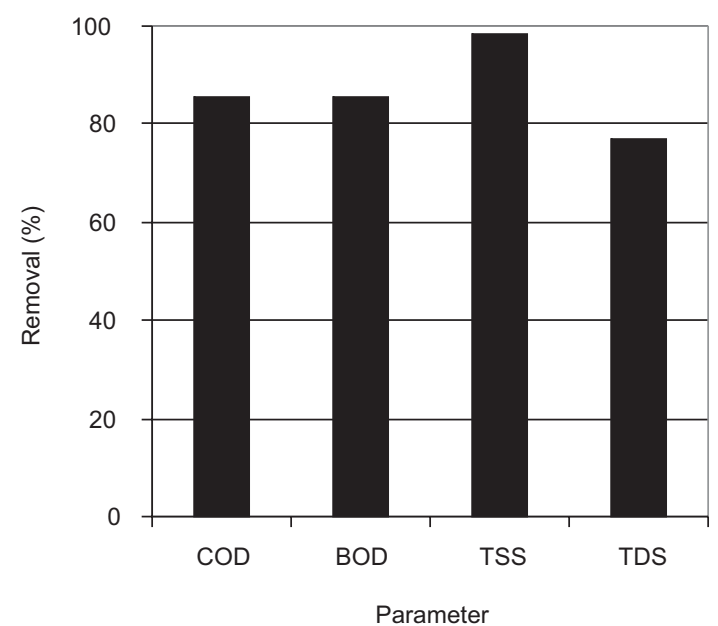

Fig. 3. Removal efficiency of different parameters at the optimum conditions with the combination of alum and lime.

treatment increased the $\mathrm{pH}$ of the supernatant due to addition of lime, which was then neutralized with dilute sulfuric acid before the tests where required. Analysis results of treated effluent were presented in Fig. 3. The concentrations of all parameters were decreased very much. COD and BOD were still above the NEQS permissible limits though, TSS and TDS values (35 mg/L and $2560 \mathrm{mg} / \mathrm{L}$, respectively) met the NEQS limits (Table 1).

\section{Conclusion}

The slaughterhouse wastewater was characterized for $\mathrm{pH}, \mathrm{BOD}, \mathrm{COD}$, TDS, and TSS parameters, which were alarmingly above the permissible limits of National Environmental Quality Standards (NEQS, 1993). The high organic content in slaughterhouse wastewater and the absence of treatment facility was causing a high pollution loading to the receiving water body. BOD and COD values were about seventy three and forty six times of the NEQS (1993) values, respectively. For the treatment of slaughterhouse wastewater, the coagulation process was tested. Lime and alum were used both individually and in combination for coagulation/ flocculation process. The optimum COD removal was $92 \%$ with $2.5 \mathrm{~g}$ alum for the treatment of $500 \mathrm{~mL}$ slaughterhouse wastewater and produced a sludge volume of $400 \mathrm{~mL}$. Lime ( $2.5 \mathrm{~g})$ reduced about $72 \%$ COD and produced sludge volume of $80 \mathrm{~mL}$ for the treatment of $500 \mathrm{~mL}$ wastewater. When increasing dose of alum was dosed from 5 to $9 \mathrm{~g}$ in addition to $2.5 \mathrm{~g}$ of lime to $500 \mathrm{~mL}$ effluent, optimum COD removal was 
$85 \%$ with $130 \mathrm{~mL}$ sludge. With optimized conditions percentage removal of COD, BOD, TSS, and TDS was $85.46 \%, 85.4 \%, 98.44 \%$ and $77.3 \%$, respectively. It was concluded that lime and alum reduced the pollution load of slaughterhouse wastewater with fast sludge settling, when used in combination.

\section{References}

Aguilar, M.I., Saez, J., Llorens, M., Soler, A., Ortuno, J.F., Meseguer, V., Fuentes, A. 2005. Improvement of coagulation-flocculation process using anionic polyacrylamide as coagulant aid. Chemosphere, 58: 47-56.

Amuda, O.S., Alade, A. 2006. Coagulation/flocculation process in the treatment of abattoir wastewater. Desalination, 196: 22-31.

APHA 1998. Standards Methods for Examination of Water and Wastewater. $5^{\text {th }}$ edition, American Public Health Association, Washington, DC., USA.

Bull, M.A., Sterritt, R.M., Lester, J.N. 1982. The treatment of wastewaters from the meat industry: A review. Environmental Technology Letters, 3: 117-126.

Johns, M.R. 1995. Developments in wastewater treatment of the meat processing industry. Bioresource Technology, 54: 203-216.

Khan, M.H., Bae, H., Jung, J.Y. 2010. Tetracycline degradation by ozonation in the aqueous phase: Proposed degradation intermediates and pathway. Journal of Hazardous Materials, 181: 659-665.

Khan, M.H., Jung, J.Y. 2008. Ozonation catalyzed by homogeneous and heterogeneous catalysts for degradation of DEHP in aqueous phase. Chemosphere, 72: 690-696.

NEQS. 1993. Local government and rural development notification, Ministry of Environment, The Gazette of Pakistan, Annex-I, Pakistan.

Quinn, J.M., McFarlane, P.N. 1989. Effects of slaughterhouse and dairy factory wastewaters on epilithon: A comparison in laboratory streams. Water Research, 23: 1267-1273.

Sangodoyin, A.Y., Agbawhe, O.M. 1992. Environmental study on surface and groundwater pollutants from abattoir effluents. Bioresource Technology, 41: 193-200.

Sayed, S.K.I., Zanden, J.V.D., Wijffels, R., Lettinga, G. 1988. Anaerobic degradation of the various fractions of slaughterhouse wastewater. Biological Wastes, 23: 117-142.

Sayed, S.K.I. 1987. Anaerobic treatment of slaughterhouse wastewater using the UASB process. Ph.D. Thesis, Agricultural University of Wageningen, Wageningen, The Netherlands.

Shaw, D.J. 1966. Introduction to Colloid and Surface Chemistry. $1^{\text {st }}$ edition, pp. 125-172, Butterworth, London, UK.

Tchobanoglous, G., Burton, F.L., Stensel, H.D. 2003. Wastewater Engineering Treatment and Reuse. $4^{\text {th }}$ edition, pp. 185-210. McGrawHill, New York, USA.

Thomas, A.W. 1934. Colloid Chemistry. $1^{\text {st }}$ edition., pp.325-356, McGraw-Hill, New York, USA.

Tritt, W.P., Schuchardt, F. 1992. Materials flow and possibilities of treating liquid and solid wastes from slaughterhouses in Germany. Bioresource Technology, 41: 235-245. 